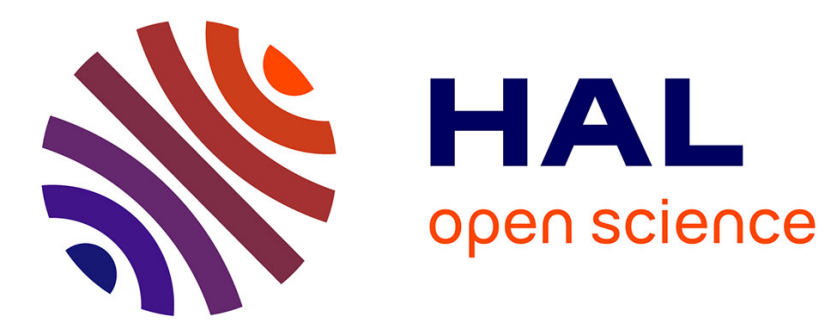

\title{
Properties and Microstructure of Thermo-Pressed Wheat Gluten Films: a comparison with Cast Films
}

Cécile Mangavel, Nicolas Rossignol, Annick Perronnet, A. Barbot, Yves Popineau, Jacques Gueguen

\section{To cite this version:}

Cécile Mangavel, Nicolas Rossignol, Annick Perronnet, A. Barbot, Yves Popineau, et al.. Properties and Microstructure of Thermo-Pressed Wheat Gluten Films: a comparison with Cast Films. Biomacromolecules, 2004, 5, pp.1596-1601. 10.1021/bm049855k . hal-01007224

\section{HAL Id: hal-01007224 \\ https://hal.science/hal-01007224}

Submitted on 5 Mar 2017

HAL is a multi-disciplinary open access archive for the deposit and dissemination of scientific research documents, whether they are published or not. The documents may come from teaching and research institutions in France or abroad, or from public or private research centers.
L'archive ouverte pluridisciplinaire HAL, est destinée au dépôt et à la diffusion de documents scientifiques de niveau recherche, publiés ou non, émanant des établissements d'enseignement et de recherche français ou étrangers, des laboratoires publics ou privés. 


\title{
Properties and Microstructure of Thermo-Pressed Wheat Gluten Films: a Comparison with Cast Films
}

\author{
C. Mangavel, ${ }^{\dagger}$ N. Rossignol, ${ }^{\dagger}$ A. Perronnet,${ }^{\ddagger}$ J. Barbot,${ }^{\dagger}$ Y. Popineau,${ }^{\dagger}$ and J. Guéguen ${ }^{\dagger}$ \\ Institut National de la Recherche Agronomique, Unité de Recherche sur les Protéines Végétales et leurs \\ Interactions, Rue de la Geraudière, BP 71627, 44316 Nantes Cedex 03, France, and Université de \\ Nantes, Institut de Recherche en Génie Civil et Mécanique, Boulevard de I'Université, BP 406, \\ 44602 Saint-Nazaire Cedex, France
}

\begin{abstract}
Wheat gluten films were prepared by thermo-pressing, and their mechanical properties were compared to those of cast films. The stress-strain relationship was established for films with various amounts of glycerol. Both relationships were quite different, revealing a different network organization. Thermo-pressed films presented higher stress values than cast films, but the effect of the glycerol amount was similar in both cases, an increase of the glycerol amount leading to a decrease of both films stress. The glycerol influence on the strain at break of thermo-pressed films was very limited, with strain values reaching a maximum around $200 \%$. The role of disulfide bridges on themomoulded films mechanical properties was investigated, and it was shown that some rearrangements and a significative protein insolubilization occurred during the process. The effective flow porosity of the protein network for thermo-pressed films was estimated by water capillary rise measurements to about 7\%. Scanning electron microscopy was used to obtain some information about the microstructure of both cast and thermo-pressed films.
\end{abstract}

\section{Introduction}

Because of the growth of environmental concerns, the interest for biodegradable materials in packaging applications has increased over the past few years. Proteins, either from plant or from animal origins, seem to be valuable candidates as raw substrates for manufacturing, and their potentials in film forming have been largely described. ${ }^{1}$ Various processes can be employed to prepare films from plant proteins. Whereas the casting process involves a solubilization step of the proteins, ${ }^{2-4}$ it is also possible to prepare films by a low-moisture process, such as thermo-pressing. ${ }^{1}$ The main advantage of this low moisture process is that it is not far from processes used presently in the plastics industry. Moreover, as the proteins do not need to be in solution, it appears to be very suitable in the case of wheat gluten, because these proteins are highly insoluble in water. ${ }^{5}$

A lot of studies have been done on wheat gluten films obtained by the casting process. ${ }^{6-8}$ In many cases, it was necessary to add some reducing agents (cysteine, sodium sulfite) or to work in denaturating conditions (highly alkaline $\mathrm{pH}$ ) in order to solubilize these proteins. In the case of the thermo-pressing process, the combination between temperature and pressure gives rise to the protein network. Some studies have been aimed at the characterization of films from various proteins (soy, pea, sunflower) obtained by thermopressing. ${ }^{9-11}$ In the case of gluten proteins, some rheological data concerning the behavior of plasticized wheat gluten upon mixing are available. ${ }^{12,13}$ Extrusion studies were also undertaken and gave interesting results: ${ }^{14}$ it was shown that extrusion of wheat proteins plasticized with glycerol was feasible under steady-state conditions, but the authors emphasized the influence of operating conditions on the aspect of extrudates. The use of a thermo-pressing process to prepare biomaterials from gluten was recently reported, and the gluten network formation upon thermosetting was investigated. ${ }^{15}$ Another study was focused on gluten plasticization with fatty acids ${ }^{16}$ in this case, the films water vapor permeability was investigated. In the present study, we tried to establish some relationships betweeen the macroscopic properties of thermo-pressed gluten films and the microstructure of the protein network. The features of thermopressed gluten films were compared to those of cast gluten films, to get information about the influence of the filmforming process on these parameters.

\section{Materials and Methods}

Materials. A commercial gluten with a protein content of $70.6 \%$ and a starch content of $11.8 \%$ was supplied by Amylum (Aalst, Belgium). Glycerol, NEMI, and other chemicals were supplied by Sigma-Aldrich (St Quentin, France).

Modification of Gluten by NEMI. A gluten dispersion (3\% in water) was stirred during $1.5 \mathrm{~h}$ in the presence of $0.1 \mathrm{M} N$-ethylmaleimide (NEMI). After the reaction time, the modified gluten was freeze-dried. The control gluten followed the same procedure (dispersion and freeze-drying) without addition of NEMI. 
Preparation of Films by Thermo-Pressing. Gluten was mixed with the glycerol in a mortar with a pestle and was allowed to stay overnight in saturating relative humidity. The blend was then placed between two Teflon sheets and pressed at $120^{\circ} \mathrm{C}$ and $200 \mathrm{bar}$ for $15 \mathrm{~min}$ in a heated press (hydraulic press "Pinette" Shell Tellus T27). A metal spacer was used to produce films of various thickness: for mechanical measurements and biochemical characterization, films thickness was about $180 \mu \mathrm{m}$. For water uptake measurements, thicker films of about $1.8 \mathrm{~mm}$ were prepared.

After cooling, the film was peeled and stored at $20{ }^{\circ} \mathrm{C}$ and $60 \% \mathrm{RH}$ (produced by a saturated solution of sodium bromide) during $72 \mathrm{~h}$. Each film was made in duplicate.

Preparation of the Protein Films by Casting. Protein films were prepared by casting as described previously. ${ }^{4}$ Briefly, gluten $(12.5 \% \mathrm{w} / \mathrm{w})$ was dispersed into $0.1 \mathrm{~N} \mathrm{NaOH}$ by using a Polytron (Kinematica, Luzern, Switzerland) homogenizer $(25000 \mathrm{rpm})$. After addition of the glycerol (glycerol/protein ratios from 0.20 to $0.61 \mathrm{w} / \mathrm{w}$ ), the mixture was stirred again and then centrifuged $(115 \times \mathrm{g}, 30 \mathrm{~min})$ to remove entrapped air bubbles. Two types of films were prepared, thin films (about $80 \mu \mathrm{m}$ thickness) for mechanical properties and biochemical composition studies and thick films (about $1.8 \mathrm{~mm}$ thickness) for water uptake measurements and scanning electron microscopy.

For the thinner films, the procedure was as follows: 30 $\mathrm{mL}$ of the solution was spread on a glass plate $(15 \times 25$ $\mathrm{cm})$ covered with a polyester sheet and then dried during 1 $\mathrm{h}$ at $70{ }^{\circ} \mathrm{C}$ in a ventilated oven. The film was peeled off from the plate and equilibrated during $72 \mathrm{~h}$ in a cabinet under standard conditions of temperature $\left(20{ }^{\circ} \mathrm{C}\right)$ and relative humidity $(60 \% \mathrm{RH})$. For thicker films, the film-forming solution was poured into a Petri dish and allowed to dry 30 $\mathrm{h}$ at $70^{\circ} \mathrm{C}$. In both cases, the drying time was adapted in order to have a constant weight for the material. The thick films were then taken off the Petri dish and equilibrated in the same conditions than the thin films $\left(20{ }^{\circ} \mathrm{C}, 60 \% \mathrm{RH}\right)$.

Determination of the Glycerol/Protein Ratio. Total protein content $(\mathrm{N} \times 5.7)$ was determined after digestion of the gluten films in concentrated sulfuric acid by an automated ammonia/salycilate reaction. ${ }^{17}$ The method was slightly modified as follows: selenium was used as a catalyst and the digestion was realized at $300{ }^{\circ} \mathrm{C}$ during $2 \mathrm{~h}$.

The residual amount of glycerol in the films was determined by high performance liquid chromatography as previously described. ${ }^{18}$ Film samples $(500 \mathrm{mg})$ were extracted twice with water $(25 \mathrm{~mL})$ for 60 and $30 \mathrm{~min}$, and the total volume of the extract was adjusted to $250 \mathrm{~mL}$. The solution was applied on an ion-exchange column (Sucrex-CIL Ca ${ }^{2+}$ ) heated at $60{ }^{\circ} \mathrm{C}$. The glycerol was eluted by water and detected by a differential refractometer (Jobin-Yvon). The concentration was calculated by reference to a calibration curve. The measurements were done in duplicate on each film.

Taking into account the protein content in the films and assuming an average molecular weight of $121 \mathrm{~g} \mathrm{~mol}^{-1}$ for all amino acids, the glycerol content was expressed in moles of glycerol $/$ moles of amino acid.

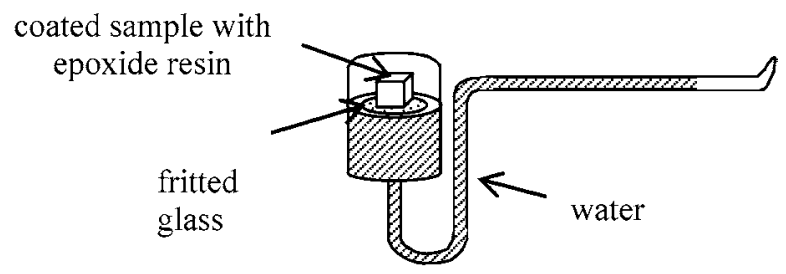

Figure 1. Principle of a Baumann device.

Residual Water. The water content in films was determined from weight difference of the samples $(500 \mathrm{mg})$ after $24 \mathrm{~h}$ drying in a desiccator containing $\mathrm{P}_{2} \mathrm{O}_{5}$ under reduced pressure. Two measurements were made on each film.

Mechanical Properties. Mechanical properties were evaluated on 5A-type dumbbell-shape specimens according to the ISO-527-2 standard (gauge length $l_{0}=20 \mathrm{~mm}$ ). Film thickness was evaluated at five points with a micrometer. Elongation at break and tensile strength were measured in a cabinet (ERATIS, Bouloc, France) at $20{ }^{\circ} \mathrm{C}$ and $60 \% \mathrm{RH}$ with a Synergie 100 MTS Systems device (Créteil, France), equipped with a $10 \mathrm{~N}$ load cell. The initial grip separation was set at $50 \mathrm{~mm}$, and the cross-head speed was $20 \mathrm{~mm}$ $\mathrm{min}^{-1}$. Each measurement was replicated five times.

Prolamin Composition by SE-HPLC. Size distribution and aggregation of prolamins in gluten and in gluten films were analyzed by SE-HPLC on a Superose 6 column $(1 \times$ $30 \mathrm{~cm}$; flow rate $0.3 \mathrm{~mL} / \mathrm{min}$; detection at $220 \mathrm{~nm}$ ) equilibrated in $12.5 \mathrm{mM}$ sodium borate buffer $0.1 \%$ SDS (Sodium Dodecyl Sulfate). Samples were prepared by a three-step extraction. ${ }^{19,20}$ The first step consisted of stirring in $12.5 \mathrm{mM}$ sodium borate buffer $\mathrm{pH} 8.5,0.5 \%$ SDS. Residual proteins were sonicated under controlled conditions $(6 \mathrm{~W}, 30 \mathrm{~s})$ in $12.5 \mathrm{mM}$ sodium borate buffer with $2 \%$ SDS after being stirred overnight. In addition a third extraction step was achieved on the pellet with $12.5 \mathrm{mM}$ sodium borate buffer, 2\% SDS containing 1\% DTT (Dithiothreitol). All three protein extracts were analyzed by SE-HPLC. Chromatographic patterns of the first solubilisation step were divided into three peaks $-\mathrm{P} 1, \mathrm{P} 2$, and $\mathrm{P} 3$-corresponding respectively to large-size glutenin polymers $\left(M_{\mathrm{w}}>500 \mathrm{kDa}\right)$, medium-size glutenin polymers $\left(500 \mathrm{kDa}<M_{\mathrm{w}}<70 \mathrm{kDa}\right)$ and gliadin monomers. Each type of protein was quantified by measuring the surface areas of peaks and was normalized with respect to the total area.

Scanning Electron Microscopy. Films sections were observed by scanning electron microscopy (SM 840A, JEOL, Tokyo, Japan) with an accelerating voltage of $5 \mathrm{kV}$; samples were previously cut with a scalpel and gilded. The thickness of the gold layer was about $15 \mathrm{~nm}$.

Water Uptake Measurements. The experimental device for capillary rise, also called a Baumann apparatus, is shown in Figure 1. Samples (about $1.8 \mathrm{~mm}$ thickness) were cut in order to expose their inner structure to water rising. The size of the samples was adapted in order to have a section of 0.2 $\mathrm{cm}^{2}$ (in contact with water) and a total volume comprised between $0.2 \mathrm{~cm}^{3}$ and $0.5 \mathrm{~cm}^{3}$.

They were then coated on each of their faces (except the contact surface) with epoxide resin (Buehler, Limonest, France) to prevent their swelling and put on fritted glass in 

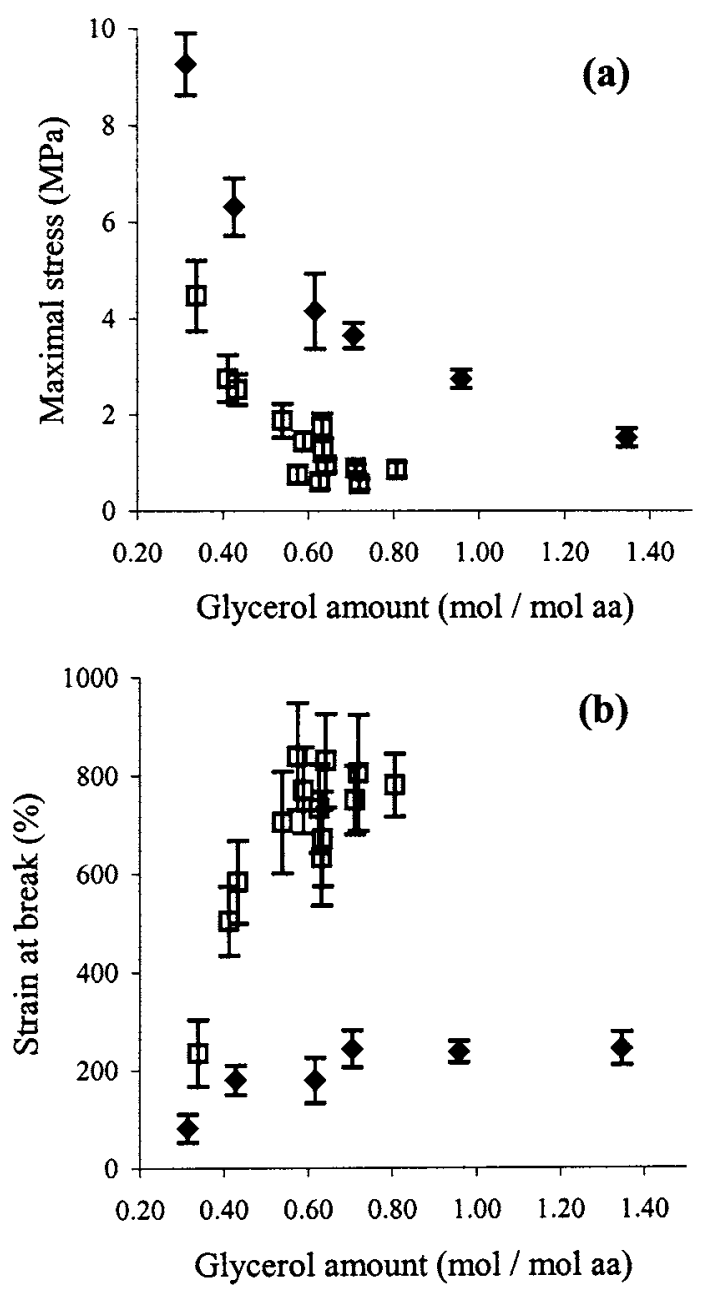

Figure 2. Evolution of maximal stress (a) and of strain at break (b) of thermo-pressed $(\checkmark)$ and cast $(\square)$ wheat gluten films versus the molar amount of glycerol.

contact with distilled water. The absorbed water volume versus time data was then recorded as water ascended into the sample.

\section{Results and Discussion}

Mechanical Properties of Cast and Thermo-Pressed Gluten Films. Thermo-pressed gluten films were prepared with various amounts of glycerol as a plasticizer. Assuming a mean molecular weight of $121 \mathrm{~g} \mathrm{~mol}^{-1}$ per amino acid, the mechanical properties of thermo-pressed films versus the molar ratio of the glycerol per amino acid are plotted in Figure 2. A set of data previously obtained for cast films ${ }^{4}$ is also reported for comparison. For the same molar glycerol ratios, thermo-pressed films presented always a higher stress and a lower strain than cast films (for example $4.15 \pm 0.78$ $\mathrm{MPa}$ and $179 \pm 46 \%$ for thermo-pressed films versus 0.60 $\pm 0.15 \mathrm{MPa}$ and $732 \pm 90 \%$ for cast films at a glycerol/ amino acid ratio of 0.62); thus, we can assume that casting and thermo-pressing induced different protein network organizations. The evolution of the maximal stress of the films versus the amount of glycerol were similar in both cases (Figure 2a), in the range of $0.20-0.70 \mathrm{~mol}$ of glycerol $/ \mathrm{mol}$ of amino acid; that is, the decrease of the stress followed parallel curves for cast and thermo-pressed films. However,

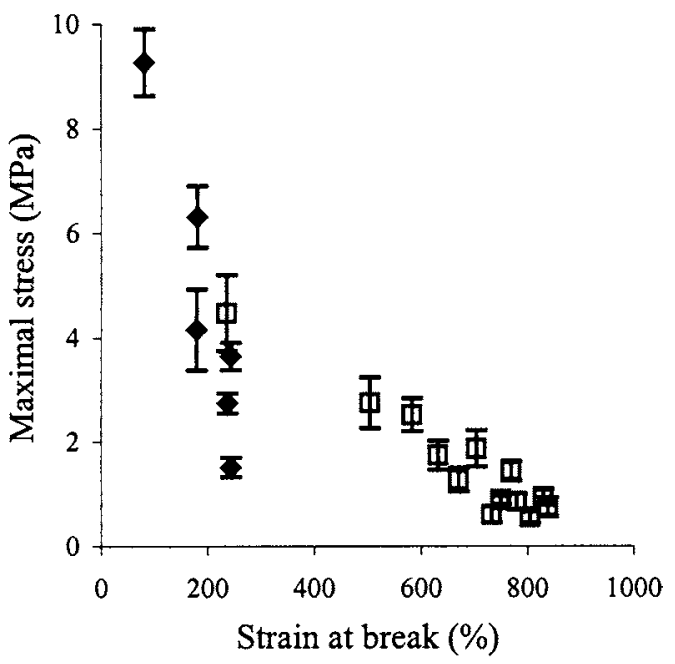

Figure 3. Stress-strain relationship for thermo-pressed $(\bullet)$ and cast $(\square)$ wheat gluten films.

the behavior of strain at break for both films was very different, thermo-pressed films being far less affected by the variation of glycerol amounts than cast films (Figure 2b).

Concerning cast films, it was previously noticed that the plasticizing effect seemed to reach a plateau beyond a threshold value of glycerol concentration: ${ }^{8}$ values of stress and strain remained constant. This was attributed to a saturation of the protein network by the glycerol molecules. It is interesting to notice that the behavior of thermo-pressed films was different. Whereas strain values remained almost constant over a glycerol amount of $0.60 \mathrm{~mol} / \mathrm{mol}$ of amino acid, stress values kept on decreasing. Thus, for larger concentrations, glycerol seemed to still have an effect on stress but not on strain: this behavior must be related to the way glycerol interacts with the protein network and to the structure of the network. The plateau value of stress, if existing in this case, might start at higher glycerol concentration; in this study, films with higher ratios than $1.35 \mathrm{~mol}$ of glycerol/mol of amino acid (protein: glycerol weight ratio 1:1) were not prepared.

Higher stress and lower strain values of thermo-pressed films compared to cast films suggested the dry process resulted in a more densely cross-linked network. Moreover, the difference in network organization was emphasized by a different stress - strain relationship for both types of films (Figure 3). Covalent bonds such as disulfide bridges could be involved, as their rearrangements could have been favored by the high-temperature conditions of the thermo-pressing process. Such an effect of temperature was shown previously: increasing the drying temperature in the casting process favored protein cross-linking, increased maximal stress, and decreased strain at break of gliadin films. ${ }^{21}$

Polymer Size and Role of the Disulfide Bridges. The aggregation state of the prolamin in the vital gluten as well as in a thermo-pressed film was analyzed by a three-step extraction procedure followed by a SE-HPLC analysis (Table 1). The transition from gluten powder to the plastic film was characterized by an important decrease of proteins extractability: whereas $70.8 \%$ of the prolamins of gluten were soluble in $0.5 \%$ SDS, this amount dropped to $35.8 \%$ for the film. In the same time, there was a clear increase of $2 \%$ 
Table 1. Prolamin Distribution of Gluten (Control and Nemi-Treated) and Gluten Films (Control and Nemi-Treated), Determined by a Three Step Extraction Procedure and SE-HPLC

\begin{tabular}{|c|c|c|c|c|c|}
\hline & \multicolumn{3}{|c|}{ first extract ${ }^{a}$} & \multirow[b]{2}{*}{ second extract ${ }^{b}$} & \multirow[b]{2}{*}{ third extract ${ }^{c}$} \\
\hline & P1 & $\mathrm{P} 2$ & P3 & & \\
\hline \multirow{3}{*}{ gluten } & 9.3 & 16.9 & 44.6 & & \\
\hline & & 70.8 & & 14.2 & 15.1 \\
\hline & 11.3 & 17.5 & 44.7 & & \\
\hline \multirow[t]{2}{*}{ gluten Nemi } & & 73.4 & & 10.5 & 16.1 \\
\hline & 1.4 & 6.8 & 27.6 & & \\
\hline \multirow[t]{2}{*}{ film } & & 35.8 & & 33.9 & 30.3 \\
\hline & 5.9 & 14.5 & 37.7 & & \\
\hline film Nemi & & 58.1 & & 27.3 & 14.6 \\
\hline
\end{tabular}

${ }^{a}$ This fraction was extracted in the presence of $0.5 \%$ SDS. ${ }^{b}$ This fraction was extracted in the presence of $2 \%$ SDS. ${ }^{c}$ This fraction was extracted in the presence of $2 \%$ SDS +DTT.

SDS soluble proteins (second extract, from $14.2 \%$ to $33.9 \%$ ) and of insoluble proteins (from $15.1 \%$ to $30.3 \%$ ). The study of the distribution of soluble proteins (i.e., the relative amounts of polymers P1, P2, and P3) in the gluten powder and in the film revealed that this insolubilization concerned all three types of soluble prolamins, gliadins ( $\mathrm{P} 3$ peak) being affected as well as glutenins soluble polymers (P1 and P2 peaks). A previous work concerning the extrusion of wheat gluten plasticized with glycerol lead to the same conclusion that gliadins could be involved in polymerization and could act as cross-linking agents. ${ }^{14}$ Note that the so-called "insoluble proteins" were finally extracted from gluten powder as well as from the thermo-pressed film for SE-HPLC analysis by a buffer containing DTT, a disulfide reducing agent, pointing out a possible involvment of disulfide bonds.

Thus, the film formation may involve the formation of covalent bonds between prolamin chains. These crosslinkages should be due to disulfide bridges rearrangements resulting from the temperature treatment applied during thermo-pressing, since sulfhydryl/disulfide exchanges occur at high temperature in gluten. ${ }^{22-25}$ It is the common suggestion that disulfide bridges may participate in the network connectivity and thus are responsible of at least a certain part of films mechanical strength. ${ }^{4,26,27}$ To further investigate the role of these bridges and their rearrangements, gluten was treated with Nemi, to block free sulfhydryl groups and thus avoid or limit disulfide bridges rearrangements. A film was prepared from this Nemi-treated gluten by thermopressing, and both the gluten and the film were analyzed by sequential extraction and SE-HPLC (Table 1). Compared to the untreated gluten, the Nemi-treated gluten presented a slightly higher content of soluble proteins, but the difference (73.4\% versus $70.8 \%$ ) was not significant. As for untreated gluten, the transition from the gluten powder to the film induced a decrease of solubility of Nemi-treated proteins. However, this loss of extractability was lower than for native gluten proteins: there were still $58.1 \%$ of soluble proteins in the Nemi-treated film, and the amount of insoluble proteins (third extract) remained unaffected between the Nemi-treated gluten and the Nemi-treated film (16.1\% versus $14.6 \%)$. A striking feature is that the amount of gliadins $(37.7 \%$ of the
Table 2. Mechanical Properties of Thermo-Pressed Gluten Films

from a Control Sample and from a Nemi-Treated Gluten

\begin{tabular}{lcc} 
& maximal stress $(\mathrm{MPa})$ & strain at break (\%) \\
\hline gluten film & $2.76 \pm 0.33$ & $190 \pm 35$ \\
Nemi-gluten film & $1.65 \pm 0.18$ & $144 \pm 28$ \\
\hline
\end{tabular}

total proteins in the film versus $44.7 \%$ in the Nemi-treated gluten) was much less affected than in the absence of Nemi, revealing that in this case gliadins were not, or less, involved in cross-linking reactions because gliadins contain only intramolecular disulfide bonds. ${ }^{28,29}$ This can be related to the fact that, when disulfide bridges rearrange, intermolecular bridges are often affected before intramolecular bridges. ${ }^{27}$ The loss of soluble proteins (first extract) in the Nemi-treated film corresponded to an increase of the fraction extracted in $2 \%$ SDS and sonicated (from $10.5 \%$ to $27.3 \%$ ). Because no reducing agent was used to obtain the second extract, this increase was due to noncovalent aggregation of proteins and to a very limited covalent cross-linking associating only a few gliadins with existing glutenin polymers.

To evaluate the role of rearrangement of disulfide bridges on mechanical properties, these films (from native gluten and Nemi-treated gluten) were submitted to tensile tests (Table 2). The film made from Nemi-treated gluten presented both lower strength and strain; blocking free sulfhydryl groups in the gluten by Nemi thus limited strongly the protein aggregation by covalent bonds and affected the whole network resistance. The effect on stress is supposed to be related to a lower density of intermolecular cross-linkages, as the presence of Nemi will unfavor rearrangements. The effect on strain, though less important, is significant and might be related to the shorter mean length of the gluten polymers. However, the whole network rearrangements induced by the Nemi treatment cannot be completely explained on the basis of what was previously observed after increased cross-linking treatment (thermal treatment, for example), since there was a simultaneous decrease of both stress and strain. Most of the time, the strain decrease was coupled with a stress increase. ${ }^{21,30,31}$ We can suggest that hindering disulfide bridges rearrangements prevented network development, thus leading to an overall decrease of films mechanical properties.

Microstructure of the Network. Parallel and crosssections of a thermo-pressed and a cast wheat gluten film were examined by SEM in order to have information about their inner microstructures (Figure 4). The main feature of the parallel section of the thermo-pressed film (Figure 4a) was the presence of some residual starch granules that were not destroyed during the thermo-pressing process. The micrograph of the cross section showed a rough microstructure, with pores of about $200-500 \mathrm{~nm}$ in diameter (Figure 4b). The microstructures observed here for a thermo-pressed gluten film were quite similar to those reported for a soy protein isolate film produced by thermal compaction, thus suggesting that the process may play a major role in these features. ${ }^{32}$ This was confirmed by the comparison with the microstructure of a cast gluten film, which was very different (Figure 4, parts c and d). First of all, the parallel section did not show large size starch granules as in thermo-pressed films 

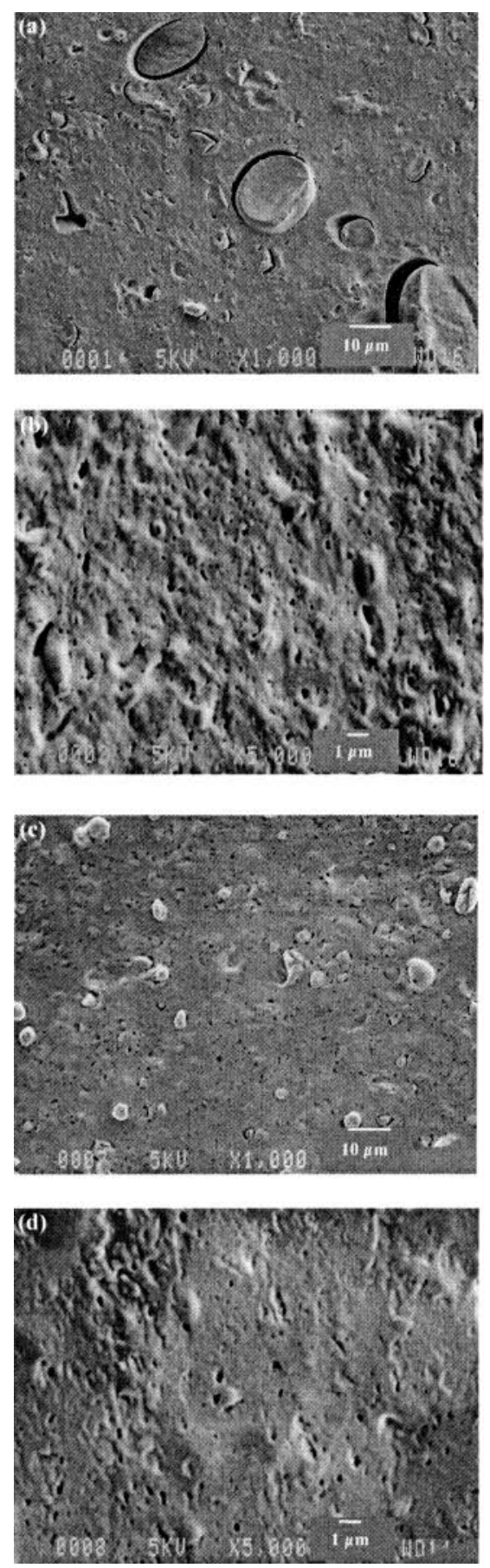

Figure 4. SEM micrographs of gluten films: (a) parallel $(\times 1000)$ and (b) cross-section $(\times 5000)$ of a thermo-pressed film; (c) parallel $(\times 1000)$ and $(d)$ cross-section $(\times 5000)$ of a cast film.

but only small ones, probably damaged. The large starch granules were probably lost by pelleting during the centrifugation of the film-forming solution before casting. Some starch granules might also have been damaged by the presence of $\mathrm{NaOH}$ in the film-forming solution. In addition, the cross-section of the cast film is much smoother than that of the thermo-pressed one.

The kinetics of water uptake of the cross section of a thermo-pressed film by capillarity is shown in Figure 5 . Water absorption increased until it reached a plateau. Though the reproducibility of the experiment was not excellent, we noticed that the plateau value was between 5\% and 7\% (water

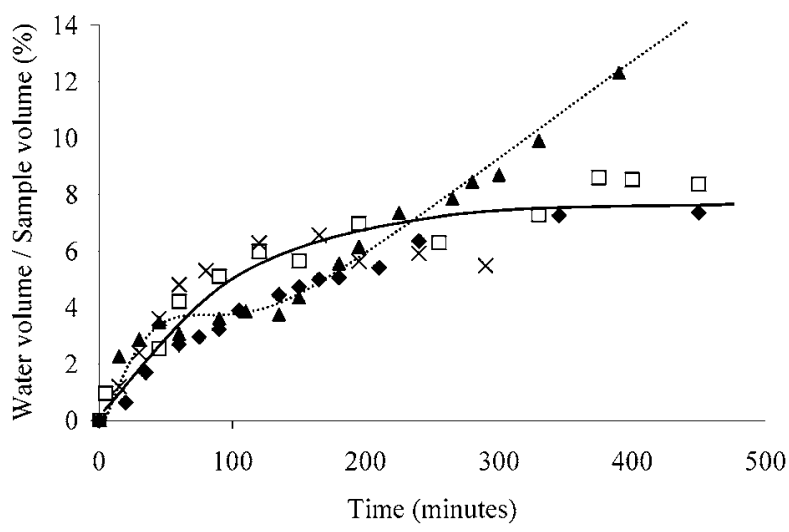

Figure 5. Water capillary rise of wheat gluten films with various sample volumes: thermo-pressed films, $(\times) V=0.20 \mathrm{~cm}^{3} ;(\diamond) V=$

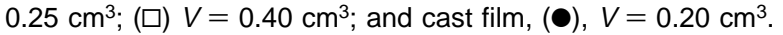

volume/sample volume) for all of the thermo-pressed samples. Since no swelling of the sample was detected, and because previous studies (not shown) had revealed that gluten proteins in thermo-pressed films were completely insoluble in water, we supposed that there was a direct relationship between the plateau value of the capillary rise and the sample porosity. Therefore, the effective flow porosity of thermo-pressed films, i.e., the volume fraction of pore space open to flow, should be in the order of magnitude of $7 \%$. These results, revealing a quite compact structure, are in accordance with the microscopic observations of thermo-pressed film sections. The behavior of cast film was very different since a very large swelling of the sample out of the resin occurred (Figure 5). This macroscopic swelling of the casting samples revealed a high degree of interaction between water and the protein network and probably a strong rearrangement of this network due to protein hydration. These results are in accordance with a previous work on $\beta$-casein cast films ${ }^{33}$ showing differences in microstructures when the films were equilibrated under various conditions of water activities. The inner microstructure of the casein film conditioned at high water activity (76\% RH) presented some porosity, whereas films conditioned at low water activity (11\% RH) were completely smooth. Thus, in the case of cast films, it was not possible to determine an effective flow porosity.

\section{Conclusion}

This work enligthed the drastic influence of the process (casting or thermo-pressing) on film properties and overall protein network organization. In general, cast films presented higher elongation properties, whereas thermo-pressed films were more resistant to rupture. The properties of these films could be modulated by adjusting the amount of glycerol, but the stress-strain relationship remained very different in both cases, suggesting that the whole organization of the protein network was affected by the process. The role of disulfide bridges rearrangements due to the process was clearly demonstrated. The microstructures revealed by scanning electron microscopy, as well as the water exposure behavior of both types of films, were completely different.

Acknowledgment. This research was supported by the European Community in the frame of "Gluten Biopolymer" 
(FAIR CT 96 1979). The authors thank Amylum for providing gluten.

\section{References and Notes}

(1) Cuq, B.; Gontard, N.; Guilbert, S. Cereal Chem. 1998, 75 (1), 1-9.

(2) Gennadios, A.; Weller, C. L. Food Technol. 1990, 63-69.

(3) Gontard, N.; Guilbert, S.; Cuq, J. L. J. Food Sci. 1992, 57 (1), 190$195 / 199$.

(4) Mangavel, C.; Barbot, J.; Bervas, E.; Linossier, L.; Feys, M.; Guéguen, J.; Popineau, Y. J. Cereal Sci. 2002, 36 (2), 157-166.

(5) Shewry, P. R.; Miles, M. J.; Tatham, A. S. Prog. Biophys. Mol. Biol. 1994, 61 (1), 37-59.

(6) Gennadios, A.; Weller, C. L.; Testin, R. F. Trans. ASAE 1993, 36 (2), 465-470.

(7) Kayserilioglu, B. S.; Bakir, U.; Yilmaz, L.; Akkas, N. J. Agric. Food Chem. 2003, 51 (4), 964-968.

(8) Mangavel, C.; Barbot, J.; Guéguen, J.; Popineau, Y. J. Agric. Food Chem. 2003, 51 (5), 1447-1452.

(9) Cunningham, P.; Ogale, A. A.; Dawson, P. L.; Acton, J. C. J. Food Sci. 2000, 65 (4), 668-671.

(10) Foulk, J. A.; Bunn, J. M. Ind. Crops Prod. 2001, 14 (1), 11-22.

(11) Orliac, O.; Rouilly, A.; Silvestre, F.; Rigal, L. Polymer 2002, 43 (20), 5417-5425.

(12) Redl, A.; Morel, M. H.; Bonicel, J.; Guilbert, S.; Vergnes, B. Rheol. Acta 1999, 38 (4), 311-320.

(13) Redl, A.; Guilbert, S.; Morel, M. H. J. Cereal Sci. 2003, 38 (1), 105-11.

(14) Redl, A.; Morel, M. H.; Bonicel, J.; Vergnes, B.; Guilbert, S. Cereal Chem. 1999, 76 (3), 361-370.

(15) Domenek, S.; Morel, M. H.; Bonicel, J.; Guilbert, S. J. Agric. Food Chem. 2002, 50 (21), 5947-5954.

(16) Pommet, M.; Redl, A.; Morel, M. H.; Guilbert, S. Polymer 2003, 44 (1), $115-122$.
(17) Wall, L. L.; Gehrke, C. W. J. AOAC Int. 1975, 58 (6), 1221-1226.

(18) Sanchez, A. C.; Popineau, Y.; Mangavel, C.; Larré, C.; Guéguen, J. J. Agric. Food Chem. 1998, 46 (11), 4539-4544.

(19) Hargreaves, J.; Popineau, Y.; Cornec, M.; Lefebvre, J. Int. J. Biol. Macromol. 1996, 18 (1-2), 69-75.

(20) Popineau, Y.; Deshayes, G.; Lefebvre, J.; Fido, R. J.; Tatham, A S.; Shewry, P. R. J. Agric. Food Chem. 2001, 49 (1), 395-401.

(21) Mangavel, C.; Barbot, J.; Popineau, Y.; Guéguen, J. J. Agric. Food Chem. 2001, 49 (2), 867-872.

(22) Sullivan, B.; Dahle, L. K. Cereal Chem. 1966, 43, 373-383.

(23) Redman, D. G.; Ewart, J. A. D. J. Sci. Food Agric. 1967, 18,15-18.

(24) McDermott, E. E.; Stevens, D. J.; Pace, J. J. Sci. Food Agric. 1969, 20, 213-217.

(25) Schofield, J. D.; Bottomley, R. C.; Timms, M. F.; Booth, M. R. J. Cereal Sci. 1983, 1, 241-253.

(26) Roy, S.; Weller, C. L.; Gennadios, A.; Zeece, M. G.; Testin, R. F. J. Food Sci. 1999, 64 (1), 57-60.

(27) Morel, M. H.; Bonicel, J.; Micard, V.; Guilbert, S. J. Agric. Food Chem. 2000, 48 (2), 186-192.

(28) Gianibelli, M. C.; Larroque, O. R.; MacRitchie, F.; Wrigley, C. W. Cereal Chem. 2001, Online review.

(29) Shewry, P. R.; Halford, N. G. J. Exp. Bot. 2002, 53 (370), 947958.

(30) Ali, Y.; Ghorpade, M.; Hanna, M. A. Ind. Crops Prod. 1997, 6, 177184.

(31) Micard, V.; Belamri, R.; Morel, M. H.; Guilbert, S. J. Agric. Food Chem. 2000, 48 (7), 2948-2953.

(32) Ogale, A. A.; Cunningham, P.; Dawson, P. L.; Acton, J. C. J. Food Sci. 2000, 65 (4), 672-679.

(33) Mauer, L. J.; Smith, D. E.; Labuza, T. P. Int. Dairy J. 2000, 10 (56), 353-358. 